\title{
Jurnal Pamomong
}

\section{MANAGEMENT GUIDANCE AND COUNSELING IN SCHOOL}

\author{
Heppi Sasmita ${ }^{1}$, Neviyarni ${ }^{2}$, Riska Ahmad ${ }^{3}$, Yarmis Syukur ${ }^{4}$ \\ ${ }^{1}$ Poltekkes Ministry of Health Padang, Indonesia \\ 2,3,4 Padang State University, Indonesia
}

\section{Informasi Artikel \\ Histori Artikel:}

Diterima 11 Juni 2021

Revisi 20 Juni 2021

Disetujui 25 Juni 2021

\section{Penulis Korespondensi:}

Heppi Sasmita,

Email:

heppisasmita@yahoo.com

\begin{abstract}
Management of guidance and counseling in schools is an activity that is carried out within a certain period of time. In order for guidance and counseling services to be carried out effectively and efficiently, in its implementation, guidance and counseling management must be carried out properly. Changes that occur in the behavior of students at school certainly provide an illustration for BK teachers to carry out various service activities, where one form of service which is at the same time the spearhead of all guidance activities is counseling activities. The provision of ongoing guidance and counseling services to students shows that the counselor profession is dynamic. The ability of guidance and counseling teachers to anticipate and choose strategies in accordance with the demands of these needs and developments will be a powerful ammunition to be able to deal with the various dynamics and changes faced For this reason, an understanding of some of the roles of guidance and counseling teachers (counselors) needs to be considered well and the success in the implementation of guidance and counseling can be seen from how the counselor is able to manage each existing service so that the counselor at school can function properly according to the educational goals that have been planned. previously in the school environment.

Keyword: Management; guidance and counseling; school
\end{abstract}

\section{INTRODUCTION}

Guidance and Counseling (BK) is an important element in supporting the success of educational programs in schools. Guidance and counseling services play a role in helping students develop themselves optimally. Guidance and counseling is a treatment system device aimed at helping each student to develop optimally according to his potential (Nursalim, 2015). Guidance and counseling services are an inseparable part of the overall educational program in schools so that good planning is needed so that the BK program and the school program can be in line with both and there are no clashes.

Guidance and counseling services in schools is an attempt to assist students in the development of personal life, social life and learning activities. Guidance and counseling 
services facilitate the development of individual, group and classical students according to their needs, potentials, talents, interests, developments, conditions, and opportunities. This service also helps overcome weaknesses and obstacles as well as problems faced by students.

The Ministry of National Education mentions the importance of guidance and counseling services regarding efforts to facilitate students to be able to develop their potential or achieve developmental tasks involving physical, emotional, intellectual, social, and moral-spiritual aspects (Menteri Pendidikan RI, 2008). Students as the main element of the school are individuals who are developing so they are vulnerable to problems that can affect their learning outcomes. Therefore, the presence of guidance and counseling services in schools is very necessary but in its implementation there are still various obstacles. The obstacles include BK teachers who do not have a background in the field of guidance and counseling, the unbalanced ratio between BK teachers and students, ideally 1:150 in accordance with Permendiknas Number 39 of 2009 concerning Fulfillment of Teacher Workloads and Education Unit Supervisors, Article 1 paragraph 6 states that the teaching burden of guidance and counseling teachers (counselors) is to provide guidance and counseling for at least 150 (one hundred and fifty) students per year in one or more educational units. In addition, there are still many schools that have not managed BK services properly (Menteri Pendidikan RI, 2009). For example, preparing BK programs is not based on feasibility studies, analysis results, and does not involve stakeholders schoolto formulate program plans. This condition will certainly have an effect on the implementation of BK in schools for that, of course, management is needed so that it can achieve the goals of education that have been set to run well.

Tohirin (2013) argues, in general the meaning of management itself is a process of planning, organizing, directing, and supervising the efforts of organizational members and the use of other organizational resources in order to achieve the organizational goals that have been set. Sugiyono (2012) states that guidance and counseling management is an activity that begins with planning guidance and counseling activities, organizing activities and all supporting elements of guidance and counseling, mobilizing human resources to carry out guidance and counseling activities, motivating human resources so that guidance and counseling activities achieve common goals and evaluate guidance and counseling activities to find out whether all service activities have been carried out so that the results 
can be known. Thus, it can be understood that the management of guidance and counseling is an organizing activity in which there is planning, implementation of activities, and evaluation so that the activities carried out can run effectively and well organized.

The implementation of good management in schools for guidance and counseling services will result in efficiency and effectiveness. Because with the guidance and counseling in schools, it is possible to develop the potential of students to achieve independence. For this reason, good implementation and service strategies are needed so that educational goals can be carried out properly.

\section{METHOD}

Researchuses the type of library research, namely research whose data is obtained from literature studies or related literature, then analyzed theoretically-philosophically, concluded and raised by relevance and contextualization. The approach used is a phenomenological approach to see how the management of guidance and counseling in schools so that the goals of Islamic education are achieved effectively, efficiently and productively

\section{DISCUSSION}

\section{Basic Concepts of Management and Its Application in Counseling Guidance}

Management is a process by which the implementation of a certain goal is carried out and monitored. According to, management is the achievement of predetermined goals through the activities of other people. Management is a typical process, which consists of planning, organizing, directing and controlling actions carried out to determine and achieve the goals that have been set through the use of human resources and other sources (Simamora, A.L \& Suwarjo, 2013).

Some of the explanations above explain that management is a series of arrangements or organizations to achieve a certain goal, in other words that management is a series of activities where a process of planning, organizing, directing and controlling is needed to achieve certain goals. In its application to counseling guidance activities, it can be taken a basis for the management of counseling guidance services that refer to the basic concepts and management functions so that counseling guidance services are organized and run 
smoothly in order to achieve a goal by optimizing students so that they can direct, organize, and understand themselves and are able to make decisions independently and purposefully.

Guidance is a process in which an expert provides assistance to individuals who use processes, methods and materials in an effort to help individuals to solve their problems independently, and counseling is a process of assistance provided by an expert through interviews with individuals in order to find out and provide solutions to clients. Therefore, guidance and counseling is a very important component in schools. According to Frank Person, guidance and counseling is a means given to an individual so that he can choose and prepare himself to take on responsibilities and make progress in the responsibilities he chooses. (Yahya, 2020). Guidance and Counseling is intended to develop a person's identity and explore the potential that exists within him. This indicates that guidance and counseling are indispensable for cognitive, effective and psychomotor development if there is harmony between subject teachers and counseling guidance teachers.

The potential that is explored in the identity of a student is directed to all areas of guidance, namely the field of personal guidance, the field of social guidance, the field of study guidance and the field of career guidance. This field is in line with the position of guidance and counseling formulated in Permendiknas No. 22 of 2006 concerning the standard content of Elementary and Secondary education units, Guidance and Counseling as activities related to self-development from personal, social learning and career problems (Rachmawati, dkk., 2013). Exploring the potential of a student in finding his identity must be accompanied by the services of a BK teacher who understands Guidance and Counseling, a good Guidance and Counseling service must be with good managerial as well, this is intended so that in exploring the identity of a student it can be more positive. Good Counseling Guidance Teachers or Counselors are managerial and competent in their services in order to realize the vision and mission of the school concerned.

Achieving the goals of Guidance and Counseling must be more systematic to achieve educational goals in schools. Guidance and counseling are never separated from planning, because unplanned guidance and counseling can give an indication of inefficient achievement of educational goals. Thus, there is a need for guidance and counseling 
purposes. According to (Wekke, 2018) research objectives are broadly classified into two types of research, namely:

1. General Objectives. The general purpose of Guidance and Counseling is in accordance with the objectives of education, which is stated in the Law on the National Education System (UUSPN) of 1989 (UU No.2/1989), namely the realization of all Indonesian people who are intelligent, have faith and fear God Almighty and have good character noble, have knowledge and skills, physical and spiritual health, and have responsibilities to the nation and state.

2. Special Purpose. The Specific Objectives are in accordance with Permendiknas No. 22/2006 concerning the standard content of Elementary and Secondary education units, Guidance and Counseling as activities related to self-development from personal, social learning and career problems. Of course the Specific goals that must be achieved are related to the personal aspects of a student.

With the guidance and counseling, a student feels more cared for by the teacher, so that the potential that will be explored in a student is much better. The openness of students in all aspects of their personal problems can relieve the burden that is in the mind of a student. This will make it easier for students to learn at school. The learning received by students will be more effective, because quality learning is synonymous with more effective learning (Wiyono, dkk., 2021).

Guidance and counseling management is all efforts used to optimally utilize all components and information systems in the form of guidance data sets to provide guidance and counseling services in order to achieve goals. (Zamroni \& Rahardjo, 2015). Management of management-based counseling guidance services, really needs to be applied, Guidance and counseling services can refer to the main functions of management, namely planning, organizing, directing and controlling (PODC).

1. Planning (planning). In the planning process, you must first set goals and targets for the implementation of counseling guidance services, after determining and setting targets, then formulating strategies to achieve the goals and targets of counseling guidance services. Next, determine the resources needed to support the service process, then set standards or indicators of success in achieving the goals and targets of implementing counseling guidance services. 
2. Organizing . At this stage in its application the process of counseling guidance services, namely allocating resources, formulating and assigning tasks and establishing the necessary procedures for the process of guidance and counseling services. Furthermore, establishing an organizational structure that shows the lines of authority and responsibility in the implementation of services, then the activities of placing human resources in the right position.

3. Directing (directing). At this stage, activities are carried out to direct and implement the leadership, mentoring and motivational processes for BK teachers so that they can work effectively and efficiently in serving the counselee in achieving the goal of making the counselee independent. Furthermore, providing routine tasks and explanations regarding the service implementation process to match the objectives to be achieved, and explaining the established policies.

4. Supervision (controlling). In this supervisory function, the steps taken are evaluating success in achieving service goals and targets in accordance with predetermined indicators, then taking clarification and correction steps for deviations that may be found in the process of counseling guidance services, carrying out various alternative solutions to various problems related to achievement of the goals and targets of the service.

In conclusion, the process of counseling guidance services that refers to the basic concepts of management will become an track orderlyor flow in order to achieve the goals of counseling guidance services, namely optimizing the development and independence of individuals in living their lives in a healthy and optimal manner and individuals can regulate or manage their lives in order to achieve goals. life (self-management).

\section{Guidance and Counseling Program Implementation Strategy}

Guidance and counseling services are the main facilities provided by a counselor in the process of developing student character. Because counselors as agents of change must of course be more open to clients or students, in carrying out their duties counselors are required to carry out counseling guidance by compiling a counseling guidance program that refers to the components of counseling guidance services according to (Purwaningrum, 2018), namely:

1. Basic services or Guidance Curriculum. Basic service is a process to provide assistance to all counseling through activities that are prepared in a classically structured manner that 
are presented systematically or structured in carrying out their duties both long and short term in accordance with the development tasks needed to develop the ability to choose and make decisions in living their lives. Basic services are classified into classical guidance, orientation services, information services, group guidance, and data collection services. A good basic service gives an indication of the pattern of counseling thought, the pattern of life exemplified by a counselor will be attached to the counseling person, therefore in shaping the personality of a counselor must be accompanied by a competent counselor.

2. Responsive Service. Responsive services are carried out in order to pay attention to counseling quickly to solve and provide solutions to the problems they face. Responsive services aim to respond quickly to problems that occur to counseling related to personal, social and educational problems. Counselors are required to pay more attention to the surrounding environment so that various kinds of problems faced by counseling can be responded quickly. Meanwhile, responsive services accompany aspects of individual and group counseling, referrals as referrals or transfer of hands, collaboration of subject teachers and or homeroom teachers, collaboration of parents, collaboration of related parties outside school, consultation, peer guidance, case conferences, home visits. and all who pay attention to the environment of a counselor.

3. Individual planning. Individual planning is carried out to provide solutions to counseling in choosing decisions and determining life goals for the future of a counselor by understanding the strengths and weaknesses of a counsellor. Individual service activities are intended to assist all counseling in planning, formulating and implementing activities that encourage their future in terms of their weaknesses and strengths, and provide an overview of the opportunities that exist around them. (Budi, dkk., 2020).

4. System Support. System support is part of the support in the implementation process and the smoothness of counseling guidance services (Rachman, dkk., 2020), The development of the system can provide excellent and effective service to counseling, development requires the development of a system to facilitate counseling in communicating and telling stories about personal problems. Actually system services can be used as an important component in planning programming components, however, the implementation of this system is often forgotten by most people.

However, the system service is still an alternative for counseling to communicate with the counselor. When viewed from the nature of the service system, it is easier for 
counselors to carry out administration and management of guidance and counseling programs. The time limit through this service is the main thing that must be seen and applied to counseling to make it easier on all sides. Viewed from the point of view of this system service, the activities carried out can support the three components above, these activities areDevelopment Networking and management activities.

The types of counseling services carried out by guidance and counseling teachers are as follows: a) Orientation services, namely services that help students understand the new environment, b) Information services, namely services that help students receive and understand various personal, social, and social information. study, career, and further education, c) Placement and distribution services, namely services that help students get the right placement and distribution in classes, study groups, majors/study programs, training programs, internships, and extra-curricular activities, d) Content Mastery Services, namely services that help students master certain content, especially competencies and or habits that are useful in school, family, and community life, e) Individual Counseling Services, namely services that assist students in alleviating their personal problems, f) Group Guidance Services, namely services that assist students in mentoring personal development, social relations skills, learning activities, careers, and decision making, as well as carrying out certain activities through group dynamics. g) Group Counseling Services, namely services that assist students in discussing and alleviating personal problems through group dynamics, h) Consulting Services, namely services that assist students and or other parties in gaining insight, understanding, and ways that need to be implemented in dealing with the conditions and or problems of students, i) Mediation services, namely services that help students solve problems and improve relations between them (Fatimah, 2009).

Guidance and Counseling services are expert services by counselors. According to (Zamroni \& Rahardjo, 2015) counselors are not actually teachers in the scientific context, so prospective counselees in the teaching unit are students, educators and education staff in the education unit. So the management of counseling services in schools is not just dealing with students. In addition, parents of students also receive counseling services from educational counselors with topics related to the problems experienced by these students. 


\section{Management of Guidance and Counseling}

Guidance and counseling have a more ideal concept, because of the functioning of the concepts and objectives of Guidance and counseling all student problems will be resolved. As one of the important elements, of course, counseling guidance must have elements and management that are neatly arranged and achieved well if managed in one quality management. Management itself is a process for planning, organizing, directing and supervising the efforts of members of the organization to obtain maximum goals. (Shafitri \& Darminto, 2020).

Basically, directed and systematic guidance and counseling management is an indicator of the manifestation and accumulation of a counselor's services, with systematic and directed guidance and counseling management providing guidance on the implementation of counseling guidance activities while eliminating the impression that counselors work incidentally and are merely curative. Implementation of guidance and counseling management is a manifestation of systematic activities where the planning of a guidance and counseling activity is to be better, how to mobilize existing human resources in the guidance and counseling organization to achieve the goals of the plan, supervise the implementation of guidance and counseling and assess the guidance and counseling activities that have been carried out.

The principles in the management of management are a) the principle of efficiency and effectiveness, namely where the management function is carried out by considering the facilities and infrastructure. b) The principle of management, where a management is carried out systematically and sequentially from each principle, c) The principle of prioritization, namely where a leader is responsible for carrying out management activities both internally and externally, d) The principle of leadership where a leader must be wise in making decisions and able to relate well with all personnel and, e) The principle of cooperation, namely cooperation is based on the organization of management related to carrying out tasks in accordance with the expertise and duties of each personnel.

Guidance and counseling management activities are said to be productive if they can produce output both in quality and quantity. The quality of guidance and counseling services is seen from the level of satisfaction of counselees who receive guidance and counseling services. While the quantity of guidance and counseling services is seen from the number of counselees who receive guidance and counseling services. The actualization 
of the implementation of guidance and counseling activities needs to be realized that it is different from other field of study teachers who have been scheduled in detail and clearly, while for counselors activities can be carried out in the classroom and outside the classroom, so that counselors are required to be able to allocate activities so that activities run well and can achieve the stated goals. The management of guidance and counseling that is directed and systematic is one indicator of the work of a directed counselor, with the management of guidance and counseling that is systematic and directed.

\section{CONCLUSION}

Management is a series of arrangements or organizations to achieve a certain goal, in its application to counseling guidance activities, it can be taken a basis for the management of counseling guidance services which refers to the basic concepts and management functions so that counseling guidance services are organized and run smoothly in order to achieve The goal is to optimize students so that they can direct, organize, and understand themselves and can make decisions independently.

Management is very important and needed in an organization, this shows that management is related to the achievement of a goal. Guidance and counseling in schools requires management in order to achieve its goals properly. Management of guidance and counseling is a management activity carried out by counselors to facilitate the function of guidance and counseling starting from planning, organizing, implementing and evaluating to achieve the goals of effective and efficient guidance and counseling by utilizing various existing resources within the educational institution.

\section{REFERENCES}

Astuti, B., Veronica, N., Purwanta, E., Novita, D., \& Risqiyan, L.N. (2020). Individual Student Planning Model to Develop Career Readiness in High School, Paper presented at Proceedings of The International Conference On Educational Research And Innovation (ICERI 2019), 12 February (pp 61-63). https://doi.org/10.2991/assehr.k.200204.012

Fatimah, S. (2009). Konsep Dasar Bimbingan dan Konseling, Jakarta: Rineka Cipta.

Menteri Pendidikan RI. (2008). Permendiknas RI No. 27 Tahun 2008 tentang Standar Kualifikasi Akademik dan. Kompetensi Konselor. Bandung: Nuansa Aulia.

Menteri Pendidikan RI. (2009). Peraturan Menteri Pendidikan Nasional Republik Indonesia Nomor 39 Tahun 2009 Tentang Pemenuhan Beban Kerja Guru dan Pengawas Satuan Pendidikan. Jakarta: MendiknasRI.

Nursalim. (2015). Pengembangan Profesi bimbingan dan Konseling. Jakarta: Erlangga. 
Purwaningrum, Ribut. (2018). Bimbingan dan Konseling Komprehensif Sebagai Pelayanan Prima Konselor, Jurnal Ilmiah Konseling, 18(1), 18-27. http://ejournal.utp.ac.id/index.php/JIK/article/view/717

Rachman, A., Sugianto, A., \& Yustina, S. (2020). Pemahaman Panduan Operasional Penyelenggaraan Bimbingan Dan Konseling Tingkat SMP. Jurnal Bimbingan dan Konseling Ar Rahman, 6(1), 29-32.

Rachmawati, U., Nusantoro, E., \& Kurniawan, K. (2013). Manajemen Bimbingan dan Konseling Tanpa Alokasi Jam Pembelajaran di SMAN 3 Semarang, Indonesian Journal Of Guidance and Counseling: Theory and Application (IJGC), 2(1), 55-61.

Shafitri, D.W.W. \& Darminto, E. (2020). Studi Implementasi Manajemen Bimbingan dan Konseling Sekolah Menengah Pertama di Surabaya Barat, Journal of BK UNESA, 11(5), 668-874.

Simamora, A.L \& Suwarjo. (2013). Manajemen Bimbingan Dan Konseling Di SMAN 4 Yogyakarta. Jurnal Akuntabilitas Manajemen Pendidikan, 1(2), 190-204.

Sugiyono. (2012). Manajemen Bimbingan dan Konseling di Sekolah. Semarang: Widya Karya.

Tohirin. (2013). Bimbingan dan Konseling di Sekolah dan Madrasah. Depok: Rajawali Press.

Wekke, I.S. (2018). Peserta Didik dan Guru Bimbingan Konseling dalam Pembelajaran, Yogyakarta: Diandra Kreatif.

Wiyono, B.D., Purwoko, B., \& Winingsih, E. (2021). Pengembangan Bahan Ajar Manajemen Bimbingan dan Konseling Berorientasi Higher Order Thinking Skills (HOTS), Jurnal Komunikasi Pendidikan, 5(1), 40-54. http://dx.doi.org/10.32585/jkp.v5i1.1040

Yahya, F. (2020). Manajemen Layanan Bimbingan Dan Konseling Di Smp Negeri 1 Aikmel Lombok Timur. At-Tadbir : Jurnal Manajemen Pendidikan Islam, 4(1), 48 56.

Zamroni, E. \& Rahardjo, S. (2015). Manajemen Bimbingan dan Konseling Berbasis Permendikbud Nomor 111 Tahun 2014. Jurnal Konseling Gusjigang, 1(1), 1-11. https://doi.org/10.24176/jkg.v1i1 